IRSH 53 (2008), Supplement, pp. I 59-I78 doi:I0.1017/So020859008003659 (C) 2008 Internationaal Instituut voor Sociale Geschiedenis

\title{
Guilds Reappraised: Italy in the Early Modern Period
}

\author{
LUCA MOCARELLI
}

\section{A NEW ERA IN THE STUDY OF GUILDS}

Over the past few decades, the interest of numerous historians has been roused by the subject of guilds, due to their widespread distribution, the way they were founded, and how they functioned. For a long time scholars wavered between two opposing views. The first, based on legal premises, held that guilds acted as an essential intermediary. Their purpose was to represent and mediate in the pre-industrial era, a period when the norm was to bargain with a collective service in exchange for a collective privilege. The second, which can be defined broadly as laissez-faire, viewed guilds as institutions with monopolistic tendencies, inflexible and ill-suited to economic development, and which acted as a brake on any form of innovation. ${ }^{\mathrm{I}}$

Obviously, two such highly ideological positions were often purely theoretical, idealistic, and anti-historical, and failed to take account of the real economic impact of guilds. Despite that, until recently those views constituted mainstream scholarship, until growing dissatisfaction on the part of various scholars inaugurated a new phase of studies on a European scale. So, at last, the complexity of the guild system has been reappraised and its links with economic cycles have been re-evaluated and the limits inherent in a purely internal study have been overcome. Convictions which were deeply rooted, but not necessarily firmly grounded, have been discredited. ${ }^{2}$

I. An excellent synthesis is to be found in Philippe Minard, "Le Corporazioni e il mondo del lavoro", in Valerio Castronovo (ed.), Storia dell'economia mondiale, II, Dalle scoperte geografiche alla crescita degli scambi (Rome, 1997), pp. 399-4 I.

2. This new approach to guilds is particularly evident in S.R. Epstein et al. (eds), Guilds, Economy and Society (Madrid, I 998), which contains the proceedings of Session B I of the XIIth World Economic History Congress. Among the most recent works the following should be mentioned: James R. Farr, Artisans in Europe, I300-19I4 (Cambridge, 2000); Steven Laurence Kaplan, La fin des corporations (Paris, 200I); Heinz-Gerhard Haupt (ed.), Das Ende der Zünfte. Ein europäischer Vergleich (Gottingen, 2002); Suraiya Faroqhi and Randi Deguilhem (eds), Crafts and Craftsmen of the Middle East: Fashioning the Individual in the Muslim Mediterranean (London [etc.], 2005); Maarten Prak et al. (eds), Craft Guilds in the Early Modern Low Countries: Work, Power and Representation (Aldershot, 2006). 
That has provided an opportunity for new investigation, and in many cases there has been a real shift in points of view, true certainly of the significance now attributed to the frequent and protracted contracts that characterized guilds in various towns. Traditionally they were considered a sign of all-out defence of privileges which had become anachronistic and were the main reason for the bankruptcy of many guilds, but now contracts are being noted once more for their significance as providing opportunities to negotiate and define rules between guilds operating in the same field. ${ }^{3}$

Other researchers have highlighted the radical change of views regarding the central theme of the relationship between guilds and technical progress in manufacturing. There has been a move away from the view that guilds were entrenched in the defence of their own privileges and so were extremely hostile to change or innovation, to the view that they served actually to spread new technical solutions, thanks to the transfer of specific skills through apprenticeship and the movement of skilled migrant workers. ${ }^{4}$

Various researchers have demonstrated the ability of guilds, in a world lacking anything like modern firms, to provide an efficient solution to complex problems of monitoring production and keeping transaction costs under control. Established and codified rules amounting to statutes enabled guilds to guarantee recognized regulations, a point of reference in the absence of specific commercial rights and a factor which helped reduce uncertainty. ${ }^{5}$

3. An example of this is in Carlo Poni, "Norms and Disputes: The Shoemakers' Guild in Eighteenth-Century Bologna”, Past E Present, 38 (1989), pp. 80-108. But see also Harald Deceulaer, "Guilds and Litigation: Conflict Settlement in Antwerp (1585-1796)", in Marc Boone and Maarten Prak (eds), Statuts individuels, statuts corporatifs et statuts judiciaires dans les villes européennes (Ghent, 1995), pp. 171-208, and Lars Edgren, "The Brotherhood of the Guild? Conflicts within the Swedish Guild System in the I 8th Century”, in Epstein, Guilds, Economy and Society, pp. I53-165. For the situation in Italy, see the recent work of Rosalba Ragosta Portioli, "Conflicts and Norms in the Silkmakers' Guild in Naples in the Sixteenth to Eighteenth Centuries", in Alberto Guenzi, Paola Massa, and Angelo Moioli (eds), Guilds, Markets and Work Regulations in Italy, I6th-19th Centuries (Aldershot, I998), pp. 2 I I-226, and Renzo Sabbatini, "Between Corporative Conflicts and 'Social Ecology': The Silk Industry in Lucca in the Early Eighteenth Century", in ibid., pp. 227-245; a good example for Milan is Elisabetta Merlo's "La lavorazione delle pelli a Milano fra Sei e Settecento. Conflitti, strategie, dinamiche”, Quaderni Storici, 27 (1992), pp. 369-397.

4. For a recent and stimulating work on this subject compare Giorgio Gottardi, "Introduzione. Le corporazioni premoderne come fonti di cultura tecnologica”, in Giorgio Petroni, Leadership $e$ tecnologica. La matrice organizzativa delle grandi innovazioni industriali (Milan, 2000), pp. I3-30, with S.R. Epstein,"Craft Guilds, Apprenticeship, and Technological Change in Preindustrial Europe", The Journal of Economic History, 58 (1998), pp. 684-713.

5. On this subject, the comments of Mantua's political commissioner in his report of 22 March I787 seem extremely clear (State Archive of Milan [hereafter, SAMi], Commercio, p.a., c. 9), especially where he observes that one of the fundamental functions of guild regulations was to guarantee "the safety of buyers and the trustworthiness of negotiations". 
Overall, it is no longer possible to ignore the part played by manufacturing crafts in protecting the customer, first by means of the guilds' certification of the quality of any of its products offered for sale and then through a guarantee that the workers involved in the various phases of production had been adequately trained through a proper apprenticeship.

This intense international debate has given rise to renewed interest in guilds in Italy too, which led to the collective research programme carried out between 1997 and 2002, encouraged by the desire critically to reconsider Cipolla's view that guilds were one of the main reasons for the decline of the Italian economy during the seventeenth century. ${ }^{6}$ Recent work, however, has emphasized that the dynamic role played by guilds did not diminish, but rather was redefined to highlight both their mercantile function as new markets began to develop and their ability to coordinate decentralized production in a pre-industrial environment. This was important information, obtained from various recent studies of guilds in Italy, and it has helped to clear urban guilds of the accusation that they were responsible for a lengthy crisis. The new research has in fact shown the importance of guilds as part of a deeper and quite well-defined process of reorganization. ${ }^{7}$

\section{THE CREATION OF A DATABASE ON ITALIAN GUILDS}

The Italian research group decided to support specific research on situations in individual towns by setting up a database, which has made it possible to substantiate many of the claims that were emerging about the function and history of guilds. The first step in the creation of the database was the implementation of a form, to make it possible to carry out research having different objectives. The form for collecting data was divided into three parts to identify not only the characteristics of each guild, but also how those guilds actually functioned. The first part of the

6. See Carlo M. Cipolla, "The Decline of Italy: The Case of a Fully Matured Economy", Economic History Review, 5 (1952), pp. I78-187. A much revised and expanded version was subsequently published as "Il declino economico dell'Italia", in Storia dell'economia italiana (Turin, 1959), and translated by Janet Pullan for republication as "The Economic Decline of Italy", in both Brian Pullan (ed.), Crisis and Change in the Venetian Economy in the Sixteenth and Seventeenth Centuries (London, I968), pp. I27-145, and Carlo Maria Cipolla (ed.), The Economic Decline of Empires (London, I970), pp. I96-2 I4.

7. The work carried out has produced two important collaborative volumes: Guenzi, Massa, and Moioli, Guilds, Markets and Work Regulations in Italy, I6th-I9th Centuries, and Paola Massa and Angelo Moioli (eds), Dalla corporazione al mutuo soccorso. Organizzazione e tutela del lavoro tra XVI e XX secolo (Milan, 2004). Markus Cerman, "Forme di organizzazione protoindustriale: i casi dell'Austria e della Boemia", Società e Storia, I7 (1994), pp. I6 I-I88, I74, had already convincingly pointed out that "the theory that claims that the move towards the countryside of preindustrial production is a result of the restrictions imposed by the city guilds in the first part of the modern age is a generalization that can in many instances be dismissed". 
form, which had to be compiled by all the scholars, is devoted to data about a guild's life, such as its name, the sector of its activity, the first time it is mentioned or documented, whether there were any mergers or splits, the date when statutes were published or perhaps revised, its patron saint, connected associations, and then, of course, the date when the guild was suppressed or ceased to exist.

The second part of the form covers relationships within the guilds and so includes anything known about terms of apprenticeship, technical regulations, the organization of governing bodies, and any limitations to admission to guilds. The third part of the form is about external relationships, with other guilds, with political authorities, and looks at the way guilds participated in public affairs generally.

The aim of the form was to place at researchers' disposal information both on the life cycle of each institution investigated, thereby facilitating cross-checking and comparison at different levels, such as urban situations, different production sectors, or professional bodies; and information on the internal functioning of guilds and their interaction with local power systems.

The work, funded by the Ministry for Universities and coordinated by Angelo Moioli, involved 40 or so scholars, who set up a database that now covers 50 Italian cities and $\mathrm{I}, 385$ guilds. Cities considered were those in Malanima's Italian urban population database, ${ }^{8}$ showing a population exceeding 10,000 inhabitants in at least 3 of the 6 dates studied: I 300 , I 400 , I 500 , I600, I700, and i 800 (Table I).

\section{QUANTITATIVE RESULTS: THE TREND IN GUILDS, THEIR PRESENCE, AND DENSITY}

We will now look at the main results obtained from the work carried out up to now, first presented by Angelo Moioli at Imperia during a congress "From Guilds to Benefit Society". The first thing to note concerns the trend among guilds in the period under study. There was continual growth until the 1760 s when the first effects of the movement to suppress guilds became apparent (Figure I). If a logarithmic scale is used, as suggested by Larry Epstein at the Imperia congress, it is possible to see that the highest rate of growth occurred before I360 (Figure 2). Such high initial rates are obviously because the numbers at the outset were very low. In fact, in I 220, when our database begins, there were only thirteen documented guilds in the whole of Italy.

If we consider one of the most significant indicators in the distribution of guilds, their number in relation to the number of inhabitants, defined as

8. See Paolo Malanima, "Italian Cities I 300-1800: A Quantitative Approach", Rivista di storia economica, I4 (1998), pp. 9I-I 26. 
Table I. Cities and guilds included in the database, I220-I800

\begin{tabular}{|c|c|c|c|c|c|c|c|}
\hline Cities & No. of guilds & Cities & No. of guilds & Cities & No. of guilds & Cities & No. of guilds \\
\hline Alessandria & 4 & Treviso & 27 & Piacenza & 39 & Cava de' Tirreni & 2 \\
\hline Asti & 1 & Udine & 17 & Reggio Emilia & 16 & Naples & 126 \\
\hline Turin & 38 & Venice & 192 & Florence & 26 & Catanzaro & 3 \\
\hline Bergamo & 7 & Verona & 61 & Lucca & 11 & Catania & 2 \\
\hline Brescia & 41 & Vicenza & 15 & Pisa & 15 & Messina & 5 \\
\hline Como & 11 & Genoa & 97 & Siena & 24 & Modica & 6 \\
\hline Cremona & 31 & Savona & 47 & Perugia & 27 & Palermo & 28 \\
\hline Lodi & 17 & Bologna & 37 & Ancona & 3 & Syracuse & 8 \\
\hline Mantua & 49 & Faenza & 5 & Ascoli Piceno & 2 & Trapani & 11 \\
\hline Milan & 69 & Ferrara & 33 & Rome & 76 & Cagliari & 12 \\
\hline Pavia & 5 & Forlì & 1 & Viterbo & 11 & Sassari & 10 \\
\hline Chioggia & 12 & Modena & 17 & L'Aquila & 4 & & \\
\hline Padua & 46 & Parma & 36 & Aversa & 2 & Total & 1,385 \\
\hline
\end{tabular}

In normal font, cities in the north (97 I guilds).

In bold, cities in central Italy (I 99 guilds).

In italics, cities in the south and the islands ( $2 \mathrm{~s}$ guilds). 


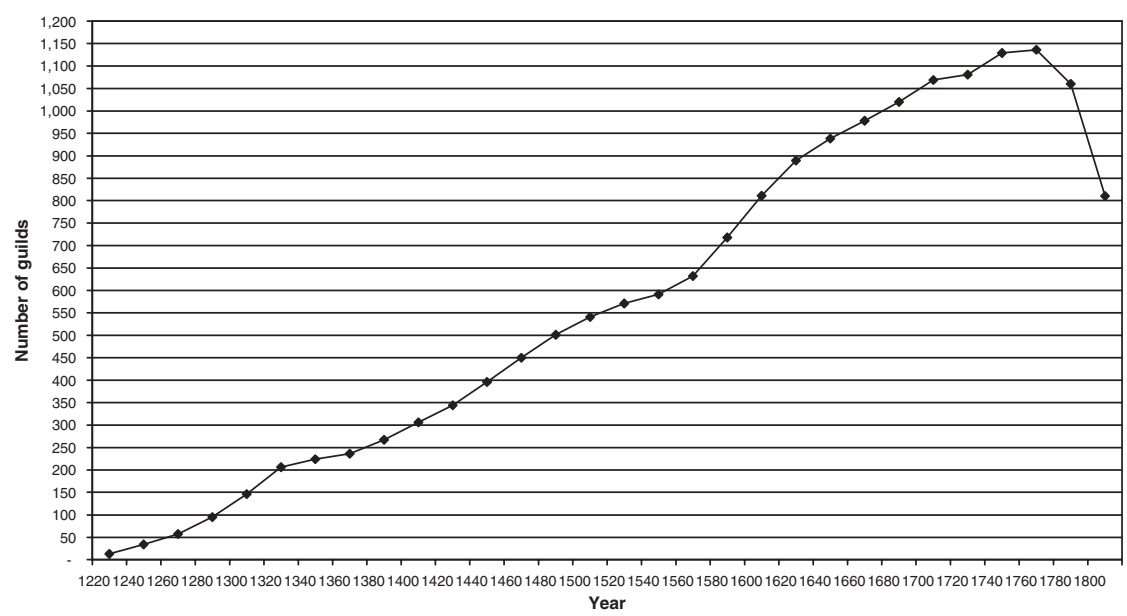

Figure I. Number of guilds in the database for the whole of Italy.

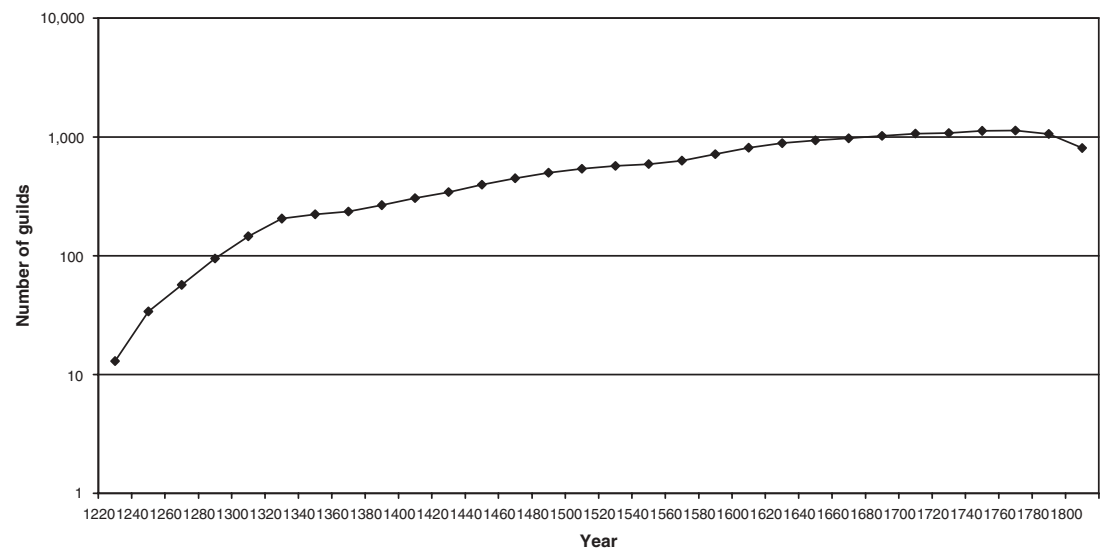

Figure 2. Number of guilds in the database for the whole of Italy (on a logarithmic scale).

"guild density", we can see that the lowest density is at the initial stage (Table 2). In I 300 , there was a guild for every 6,805 inhabitants, with the highest guild density being in central Italy ( 1 per 4,673 inhabitants), followed by the north some way behind. No data were collected for guilds in the south. From I 300 onwards the guild density increased until I 500 , by which time it had almost quadrupled to I per I, 827 inhabitants, despite the recovery in the urban population to the levels of $\mathrm{I} 300 \mathrm{fol}-$ lowing the disastrous effects of the plague of I 348 . Furthermore, by I 500 the north had the highest guild density. 
Table 2. The relationship between number of inhabitants and guilds in the main Italian towns

\begin{tabular}{|c|c|c|c|c|c|c|}
\hline Areas & & 1300 & 1400 & 1500 & 1600 & 1700 \\
\hline $\begin{array}{l}\text { North (Turin, Milan, Mantua, } \\
\text { Brescia, Cremona, Bergamo, Venice, } \\
\text { Verona, Vicenza, Padua, Genoa, } \\
\text { Savona, Parma, Bologna, Modena) }\end{array}$ & $\begin{array}{l}\text { Population } \\
\text { No. of guilds } \\
\text { Guild density }\end{array}$ & $\begin{array}{l}667,000 \\
98 \\
1 \text { per } 6,806\end{array}$ & $\begin{array}{l}452,000 \\
223 \\
1 \text { per } 2,026\end{array}$ & $\begin{array}{l}595,000 \\
418 \\
1 \text { per } 1,423\end{array}$ & $\begin{array}{l}711,000 \\
609 \\
1 \text { per } 1,167\end{array}$ & $\begin{array}{l}671,000 \\
744 \\
1 \text { per } 901\end{array}$ \\
\hline $\begin{array}{l}\text { Central Italy } \\
\text { (Florence, Rome, Perugia, Siena) }\end{array}$ & $\begin{array}{l}\text { Population } \\
\text { No. of guilds } \\
\text { Guild density }\end{array}$ & $\begin{array}{l}215,000 \\
46 \\
1 \text { per } 4,673\end{array}$ & $\begin{array}{l}106,000 \\
62 \\
1 \text { per } 1,709\end{array}$ & $\begin{array}{l}148,000 \\
80 \\
1 \text { per } 1,850\end{array}$ & $\begin{array}{l}212,000 \\
92 \\
1 \text { per } 2,304\end{array}$ & $\begin{array}{l}240,000 \\
127 \\
1 \text { per } 1,889\end{array}$ \\
\hline South (Naples, Palermo, Trapani) & $\begin{array}{l}\text { Population } \\
\text { No. of guilds } \\
\text { Guild density }\end{array}$ & $\begin{array}{l}98,000 \\
0 \\
0\end{array}$ & $\begin{array}{l}59,000 \\
10 \\
1 \text { per } 5,900\end{array}$ & $\begin{array}{l}213,000 \\
25 \\
1 \text { per } 8,520\end{array}$ & $\begin{array}{l}402,000 \\
66 \\
1 \text { per } 6,090\end{array}$ & $\begin{array}{l}347,000 \\
127 \\
1 \text { per } 2,732\end{array}$ \\
\hline Total & $\begin{array}{l}\text { Population } \\
\text { No. of guilds } \\
\text { Guild density }\end{array}$ & $\begin{array}{l}980,000 \\
144 \\
1 \text { per } 6,805\end{array}$ & $\begin{array}{l}617,000 \\
295 \\
1 \text { per } 2,091\end{array}$ & $\begin{array}{l}956,000 \\
523 \\
1 \text { per } 1,827\end{array}$ & $\begin{array}{l}1,325,000 \\
767 \\
1 \text { per } 1,727\end{array}$ & $\begin{array}{l}1,258,000 \\
998 \\
1 \text { per } 1,260\end{array}$ \\
\hline
\end{tabular}


The spread of the guilds was now unstoppable: by 1600 , at the end of a century of considerable demographic growth, the guild density had reached I per I,727 inhabitants, and by I 700 it was I per I, 260 inhabitants. However, the density recorded for 1700 was a result of a decrease in the urban population due to the seventeenth-century plague epidemics. At the beginning of the eighteenth century in the north of Italy the ratio was below I per I,, 00 , while the south registered considerable "progress", reducing the gap with central Italy, where the growth in guild density was due almost entirely to the marked increase in that in Rome.

The trend in Italy is characterized by a constant growth in the number of guilds, unlike in the Netherlands and Belgium, where the presence of a varied pattern was the result not only of different criteria used in surveys, which were of centres having at least 2,500 inhabitants in 1784 , but also of demographic dynamics which differed markedly from those in Italy, especially in the seventeenth century. ${ }^{9}$

\section{THE GUILDS AND ECONOMIC TRENDS}

It is important to know whether there was a correlation between the growth in the number of guilds and economic conditions. In medieval times guilds seem to have been established in the most economically prosperous and most densely populated areas, initially in central Italy, but soon followed by north-eastern Italy, led by Venice, which already had seventy-two guilds by I400, and then the north-west of the country. Two centuries later, from a geographical point of view the guilds continued to follow local changes in economic leadership. In I600 we find the north firmly at the top of the table, for it had become the most dynamic region of Italy, and in Venice, Milan, and Genoa, the three principal commercial centres, were to be found 306 of the 767 guilds that have been recorded.

Between I 560 and the plague of 1630 , there was a real flowering of guilds in the north of Italy, coinciding with a notable phase of economic expansion. This flowering can be attributed above all to the establishment of new guilds. Guilds were set up not in marginal sectors but rather in the cornerstones of urban economies, such as in the manufacture of textiles and clothing. Central Italy meantime was losing ground, while the south remained a long way behind (Figure 3 ). In the seventeenth and eighteenth centuries the north of Italy strengthened its position, while the situation in the south gradually approached that of central Italy. It is a phase

9. Data on the Netherlands and Belgium can be found in Jan Lucassen, Piet Lourens, and Bert De Munck, "The Distribution of Guilds in the Low Countries, 1000-1800", in Massa and Moioli, Dalla corporazione al mutuo soccorso, pp. 53-56. The differences in population trends between Italy and the Low Countries during the early modern period are shown in Jan de Vries, European Urbanization, I500-I800 (London, 1984), pp. I54-165. 


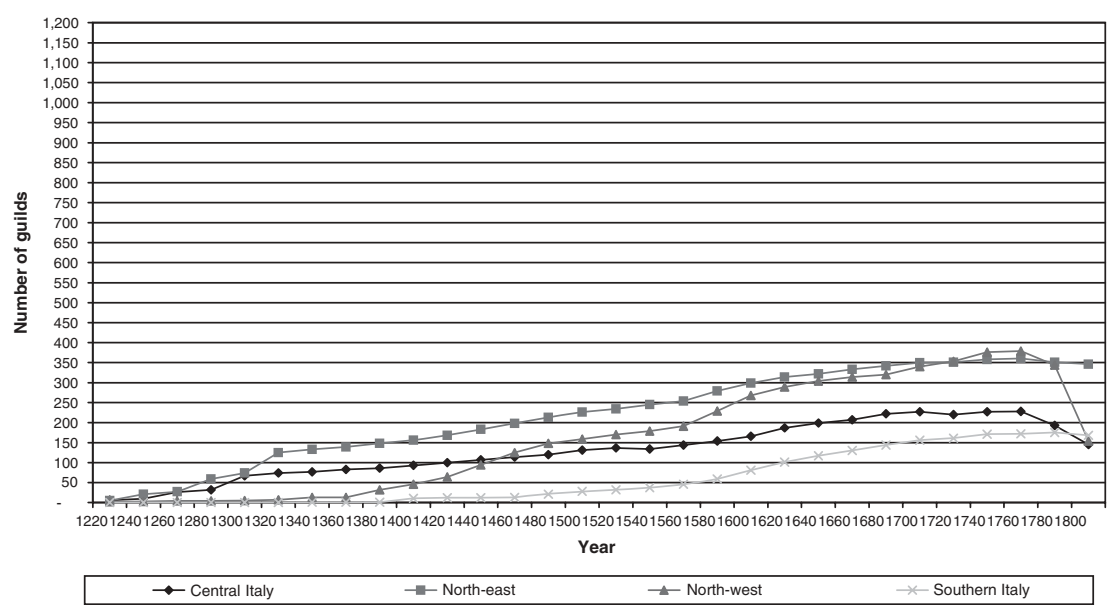

Figure 3. Number of guilds in the database by geographical region.

hard to interpret though, especially the seventeenth century, which was a difficult time for manufacturing towns in Italy, as reflected in the considerably slower growth in the number of guilds. Between i 500 and I 600 the number of guilds rose 46 per cent; between I 600 and I 700 it rose only 29 per cent.

It would seem that an important factor in this growth was the division of pre-existing guilds. Of the 170 divisions recorded in the database, 55 occurred in the period $1620-1700$, perhaps indicative of a defensive strategy by guilds to retain market share in a difficult urban context. That was the case for example in the Milan silk industry, where spinners, those who worked in imitation gold and silver (which had become somewhat of a marginal activity), and those working in gold, silver, or copper gradually became separated from silk workers. The same happened in Venice, where fragmentation of the guilds went on among manufacturers of wool, and glass.

At the same time, many new guilds that came into being at that time existed in economically marginal sectors. Naples is an example, for between I600 and I700 fifty-one guilds were set up covering such employment as stable boys, greengrocers, makers of brass nails for carriages, players of stringed instruments, trumpet players, snow sweepers, makers of shoulder bags, and so on. The considerable growth of guilds in the south can then be attributed almost exclusively to Naples, a city with one of the largest populations in Europe. In other words, it would seem that from the fourth decade of the seventeenth century the way guilds grew reflected the faded brilliance of the Italian economy.

At the beginning of the eighteenth century the guild system in Italy seems to have reached saturation. So much so that between 1700 and I 760 , 
when the process of suppression was just beginning, the number of guilds in Italy remained substantially unchanged, registering a mere 7 per cent growth. An analogous trend can be seen in the Netherlands, and even more so in the north of Belgium, where the establishment of new guilds slowed considerably between 1670 and $1787 .^{\circ}$

\section{GUILDS AND ECONOMIC ACTIVITY}

The fact that the phases of the growth cycles of guilds coincided with periods of economic expansion (the database reveals a vigorous growth in the number of guilds in the period between I 560-1620, along with the well-known expansion of medieval guilds), together with an increase in the density of guilds, prompts us to move from a quantitative to a qualitative evaluation to try to understand the reasons for their success. The guilds lasted centuries, and in the Italian states usually came to an end for political rather than economic reasons.

The first important point is the new degree of efficiency that guilds acquired during the modern era in an extensive redefinition of their characteristics. What brought that about was the considerable power accrued by mercantile capital and the prominent position of some members of craft guilds. From that point of view the case of Milan in the second half of the sixteenth century is particularly interesting. Milan was a city where guilds were to come late on the scene, with only thirteen guilds in I 400 and those mostly in the food sector for reasons of public order. Considerable growth in guilds can be seen for Milan from the second half of the sixteenth century.

Between I568 and 1627 the number of productive urban guilds increased from twenty-six to forty-four, which was greater than the dynamic development of the guilds championed by the Sforzas in the second half of the fifteenth century, when eleven new productive guilds were established. ${ }^{\mathrm{II}}$ An interesting feature is that the newly established guilds were not in new specializations but were an extension of the guilds' existing activity and covered an already well-defined and recognized professional identity.

In six cases, as Giuseppe De Luca has demonstrated, the key operators were merchant entrepreneurs, who thereby assembled under their own control in legally dependent organizations the manpower employed in the

ı. See Lucassen, Lourens, and De Munck, "The Distribution of Guilds in the Low Countries, 1000-1 800 ", p. 56.

I I. See Giuseppe De Luca, "Mercanti imprenditori, élite artigiane e organizzazioni produttive: la definizione del sistema corporativo milanese (1 568-1627)", in Alberto Guenzi, Paola Massa, and Angelo Moioli (eds), Corporazioni e gruppi professionali nell'Italia Moderna (Milan, 1999), pp. 79-I I6, especially pp. 79-80. 
various phases of production, while in the other twelve cases of craftsmen's activities the guilds were created by a small group of master craftsmen who were able to control weaker or less autonomous colleagues. ${ }^{\text {I2 }}$

The statutes of these new guilds demonstrate that they came into being with the main purpose being to ensure control and discipline. Unlike the Visconti and Sforza guilds, which focused on the quality requirements relating to goods and to technical regulations, the newly established guilds were extremely vague about technical rules but paid considerable attention to deontological norms - enrolment obligations, respect for customers' orders, and work discipline - as well as to power structures, with rules governing elections, the lengths of terms of office, and recognition of their dependence on other institutions or their own autonomy. ${ }^{13}$

Whether they were merchants or master craftsmen, their common object was to legalize and exercise control by a small group at the top, over a wide base. The different types of control, whether that was legal recognition of dependency between workforce and merchants or the creation of a formal hierarchy among workers in the same sector, can be attributed to the complexity of dissimilar production processes and the diversity of the market.

What took place during the eighteenth century in Milanese silk production illustrates this evolution. The controversy which arose in I7 3 following the publication of a decree that forbade the import of foreign cloth did not set merchants against manufacturers. Rather, the small elite at the head of the guild connected to the international market, where raw Lombard silk was exchanged for French and British cloths, clashed with the various merchants closely linked to national products and their commerce. Those merchants had the support of the guild of silk weavers, even though from a definitely inferior position as by then the best weavers "had to go round the merchants' stores in search of work". ${ }^{14}$

It was the natural result of a process that, even towards the end of the seventeenth century, made the weavers' guilds effectively a forum for "intermediaries", workers who found jobs in which they managed a workforce. Only a few individuals reached positions powerful enough to control dozens of looms. ${ }^{15}$ At the same time, they became increasingly

\footnotetext{
I2. Ibid., pp. $83-85$.

13. Ibid., pp. $85-90$.

I4. See the "Rappresentazione a sua Maestà Ces.a Catt.ca per lo ristabilimento del mercimonio nello Stato di Milano" dated Io August 1713, in the Historical Civil Archive of Milan [hereafter, HCAMi], Materie, c. 273.

I s. What made it possible is the fact that in Milan there was no obligation relating to the concentration of looms with individual masters. This is confirmed by the rejection of an appeal drawn up on 8 July i698 (HCAMi, c. 876 ) by a number of weavers demanding that no more than six looms should be used per master.
} 
subordinate to the merchant class, a state of affairs accentuated by the growing importance of imitations of foreign fashions, to the extent that merchants gained even tighter control over production so that they could have for sale articles which resembled foreign goods.

Unopposed, merchants gained the upper hand. They supplied workers with raw materials and often with looms too; they sold the cloth in contravention of the statutes; they paid their weavers increasingly in kind and maintained them in hard times. ${ }^{16}$ In practice the weavers' guild was made up of a few master craftsmen under whom were hundreds of salaried workers doing piecework. It follows that the system benefited merchants because it enabled them to simplify control of the workforce by entrusting the job to master craftsmen, enabling them to maintain quality control, which would otherwise have been impossible given the decentralization of production in rural areas. ${ }^{17}$

The phase of expansion of the Milanese silk mills in the second half of the eighteenth century brought merchants a firmer hold over producers and there was a drastic reorganization among the few master weavers still able to work their looms for themselves, albeit with their independence already reduced. ${ }^{18}$ Their function as little more than contractors was patently obvious. Secco Comneno fully realized that when he remarked "normally the master or guild member is not a worker but a mere entrepreneur who has under him a certain number of workers who work for him and are not registered as master craftsmen". ${ }^{19}$ The difference was rather between those who maintained managerial skills, enabling them to

16. The evidence for this is that in 1739 , in a proposal to lay down regulations for the sector, merchants were invited to give payment "in cash" without assuming any need for the weavers, dyers, or labourers to give goods in payment from their shops, nor food, wood, nor anything else (see the attachment marked E, Council of the Giunta del Mercimonio, i 8 September 1739, in SAMi, Commercio, p.a., c. 2).

I7. It was the same weavers' chamber which noted in 1749 that outside the city are made "cloths with less than the correct weight and width prescribed in the said statute" (see I749, "Sommario delle risposte fatte dalle Università nel particolare del ristabilimento del mercimonio", in HCAMi, Materie, c. 273).

I8. Already in 1766 the royal councillor, De La Tour, had noted how only two masters managed to work completely on their own, while the others worked for the merchants (see Carlo Antonio Vianello, Relazioni sull'industria, il commercio e l'agricoltura lombardi del '700 (Milan, I94I), pp. 25-29). By I 790 the process had become even more advanced as, although the number of workers reached I26, thanks to a favourable economic situation, only two were completely independent, despite owning the standard equipment of a minimum number of looms (three in all) and only two could still manage to work their own looms as well as those of the merchants. This information can be inferred from the "Elenco generale delle fabbriche esistenti nella città di Milano di drappi d'oro, argento e seta, vele e garze di di seta, galoni e lavorini, manifatture di lana, lino e cotone [...] giusta la visita stata fatta dalli commissari periti della Camera di Commercio nel corrente anno 1790", in Milan Archive, Chamber of Commerce, Register 405 .

19. See his comments of October 1773 , in SAMi, Commercio, p.a., c. 259. 
manage dozens of weavers and control the related running costs, and those who ran just a few looms, but still worked in the trade themselves.

While the differences within the guilds increased, the gap between the masters and the rest of the weavers widened too. It could already be seen in the act of 1768 when, with 303 looms, there were only $7 \mathrm{I}$ masters and over 700 workers and boys, ${ }^{20}$ a polarization which resulted in a growing mass of ordinary salaried workers. The guilds managed to control them only with increasing difficulty, lamenting in 1784

$[\ldots]$ the ease with which workers now at the drop of a hat abandon their employers whom they served without any preconceptions, leaving work they were doing or had just begun and not yet completed, sure to find new work independently from the employers they had abandoned, who had supplied them with credit. ${ }^{21}$

Another example of the establishment of an exclusive elite within production guilds can be seen in Venice. Many weavers there did not have enough money to purchase a loom and open their own workshops, so they were forced to take salaried work for other master weavers rich enough to have abandoned manual work completely, and to be able to dedicate themselves instead to business management and accounting for their own workshop. ${ }^{22}$

So, within the same formal and institutional framework of the guild, quite different organizations were created from their medieval counterparts. Milan and Venice are certainly no exceptions to that pattern, and a similar process can be observed for Spain.

The considerable growth in sixteenth-century Spain too saw the consolidation of powerful merchants, especially in textiles where production was intended for wider markets. It has been said that the great Spanish Verleger "controlled the guilds of each of the wool trades, subcontracting out all stages of manufacture [...]. Consequently, the work of the 'menestrales' (craftsmen), in theory independent, was in fact dependent on and subordinate to the capital of the Verleger, while still maintaining the structures of the guilds." ${ }^{23}$

20. There were exactly 335 workers and 367 boys (see the relevant note in SAMi, Commercio, p.a., cart. 240).

2I. It was the abbot of the weavers who pointed it out in a note dated 7 June 1784 , in SAMi, Commercio, p.a., c. 230.

22. See Marcello Della Valentina, "The Silk Industry in Venice: Guilds and Labour Relations in the Seventeenth and Eighteenth Centuries", in Paola Lanaro (ed.), At the Centre of the Old World: Trade and Manufacturing in Venice and the Venetian Mainland, I400-I800 (Toronto, 2006), pp. I09-I 43 .

23. See Hilario Casado Alonso, "Guilds, Technical Progress and Economic Development in Preindustrial Spain”, in Massa and Moioli, Dalla corporazione al mutuo soccorso, pp. 309-327, 317. 
In the same case, a situation was created within the guild system where a small group controlled a much wider base. In fact "there were different guilds and within one of them a few master craftsmen who controlled the production of all the craftsmen", acting like the entrepreneur of a workforce. ${ }^{24}$ The evolution of Spanish manufactured goods for export, which was very much like that recorded in Milan, confirms that guilds were by no means homogenous nor egalitarian organizations and in practice were anything but static.

However, what enabled many guilds to survive the centuries was their "genetic mutation" towards flexibility spurred on by mercantile capital, and the fact that flexibility went hand in hand with functional or structural aspects which rendered guilds extremely efficient in various ways, such as in carrying out delegated monitoring efficiently, which reduced costs. In fact,

[...] merchants engaged in long-distance trade neither bought products on anonymous markets nor struck bargains with individual producers, but concluded collective contracts with guilds that $[\ldots]$ specified prices and qualities, and sometimes provided for advance funding by merchants. By assuming quality control and the administration of advance payments, the guild effectively acted as an agent for delegated monitoring. ${ }^{25}$

Regulations and guild structure made it possible to coordinate the activities of a large number of small and scattered productive units dealing with different phases of the production process, which guaranteed that work was carried out to certain standards and reduced transaction costs. In response to merchants' strategies, guilds became ever more efficient, especially in complicated manufacturing techniques, and with wider market opportunities, which can be seen from the history of silk manufacturing. Merchants acquired sufficient power to enable them to use all possible options for organization: slowly moving spinning into rural areas; employing female workers in towns for preparatory operations such as spooling, because they could be poorly qualified which made them economical for employers; and resorting to master craftsmen only to control the more delicate phases of weaving, usually done in people's homes. Dyeing and finishing operations were then entrusted to specialized craftsmen's workshops.

\section{GUILDS AND TECHNICAL PROGRESS}

Insofar as functional aspects are concerned, I would like to examine here in more detail the relationship between guilds and technical progress, highlighting apprenticeship and technical regulations, two important

24. Ibid., p. 317.

25. See Ulrich Pfister, "Craft Guilds and Industrial Development in Early Modern Europe", in Massa and Moioli, Dalla corporazione al mutuo soccorso, pp. 287-308, 294. 
variables which can be monitored using the database. The matter is of considerable importance for the following reason. For many years guilds were thought to be organizations that opposed technical progress, but since the I990s there has been a more positive reading which has re-evaluated the role they played in disseminating knowledge and technical progress. ${ }^{26}$ However, that more recent view is itself now receiving criticism.

I refer especially to an article by Sheilagh Ogilvie, in which she strongly criticizes the rehabilitation of guilds in many of the most recent studies. ${ }^{27}$ Her contribution appears open to criticism not only for the reasons listed by Hugo Soly in the present volume, but also because it seems to be conditioned by the fact that she adopts a very restricted view. She takes as a yardstick the guilds of Würtemberg, which were special, not only because of their rural character but, more than that, because they did not produce high-quality goods. It is not by chance that her article lacks any reference to Italy, the chosen territory of urban guilds and the manufacture of luxury goods. Undoubtedly, it was in manufacturing that apprenticeship and technical standards played the most important role. Let us see then what we can discover from the database, beginning with the technical rules laid down in the statutes.

Figure 4 refers to those guilds for which it has been possible to find information on their technical regulations. It clearly shows that most of them, 702 out of I, I55, or 60.8 per cent, make no mention of technical regulations in their statutes. It would be wrong, however, to deduce straight away that technical regulations were of little importance, or to belittle their significance not only for maintaining quality standards, but also for the transmission of technical information and expertise. Actually, guilds everywhere, including those in Italy, were extremely varied and distinct, and in the course of time they covered sectors and activities that did not require technical regulations or had limited economic importance. One example is purely mercantile activities. In order for them to be carried out, it usually was enough to pay a registration fee that corresponded to the economic importance of the activity itself. A second example is activities which, mostly because of their simplicity, did not demand any particular technical requirements, almost always the case with unskilled work.

It is therefore clearly important to verify which guilds had official technical regulations. From the database it is possible to confirm that of

26. Gottardi's comments are extremely interesting here since he considers the technological heritage of guilds from a long-term perspective; see Giorgio Gottardi, "Innovation and the Creation of Knowledge in Italian Industrial Districts: A System Model”, in F. Belussi and G. Gottardi (eds), Evolutionary Patterns of Local Industrial System (Aldershot, 2003), pp. 27-39. 27. See Sheilagh Ogilvie, "Guilds, Efficiency, and Social Capital: Evidence from German Protoindustry”, Economic History Review, 57 (2004), pp. 286-333. 


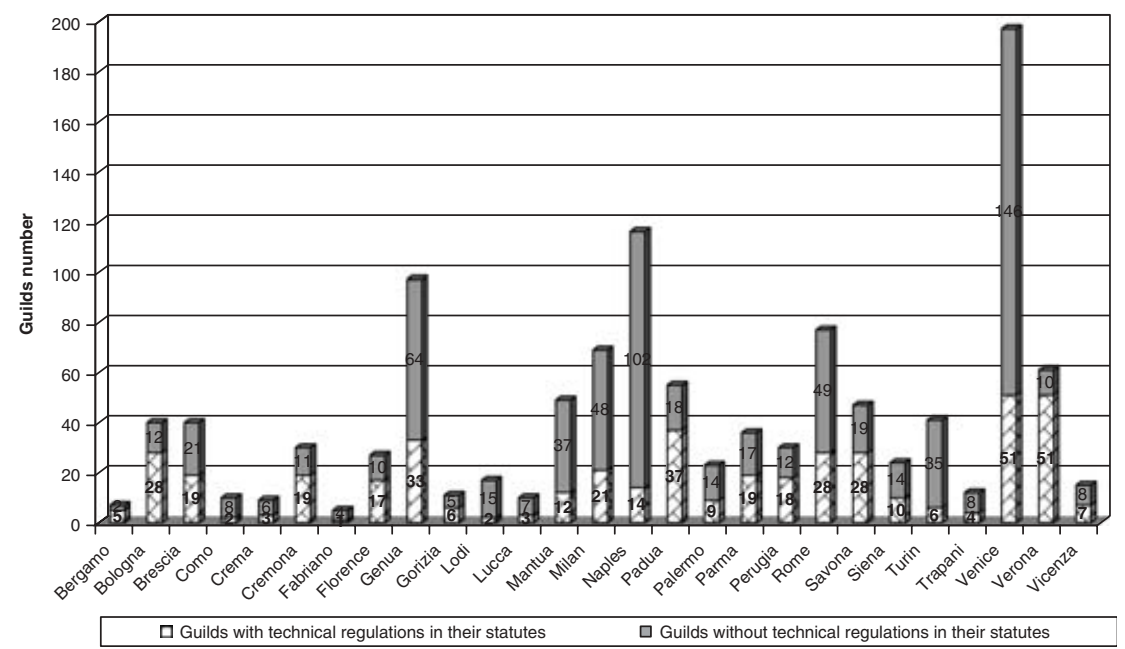

Figure 4. Number of guilds with technical regulations, in various cities in Italy in the early modern period.

the 453 guilds with technical regulations, it was the textile sector that had the highest number (94), closely followed by the food sector. They were the most significant sectors in Italian manufacturing and carried great social and public weight. If we consider the 198 guilds in the textile sector, we see that their technical regulations were concentrated in branches that produced higher-quality goods: woollen mills and above all silk manufacture. With the exception of Milan, all the important silk centres (Florence, Genoa, Turin, Venice, Lucca, Bologna, and Naples) had extremely detailed technical regulations covering the weaving, spinning, and dyeing of silk.

For our point of view then, the statutes of the silk weavers of Venice provide a typical example. They contain dozens of articles concerning the essential characteristics required of looms, the dimensions and thicknesses of cloths, and all the different working processes. In the same way, the silk dyers of Genoa had to follow extremely detailed regulations aimed largely at preventing frauds, such as the categorical prohibition of the use of woad instead of indigo and madder instead of cremex. ${ }^{28}$

Where work was complicated or a high level of skill was required, technical regulations always had great importance, confirmed by the fact that other internationally successful products were manufactured in similar ways. It certainly applied to metalworking, where technical regulations were issued by 52 associations out of $\mathrm{I} 25$, and to leatherwork, where 50 out of Ios guilds issued them.

28. This information was obtained from the database compiled by the Italian working group and is taken from index cards nos I 255 (silk weavers in Venice) and I 272 (silk dyers in Genoa). 


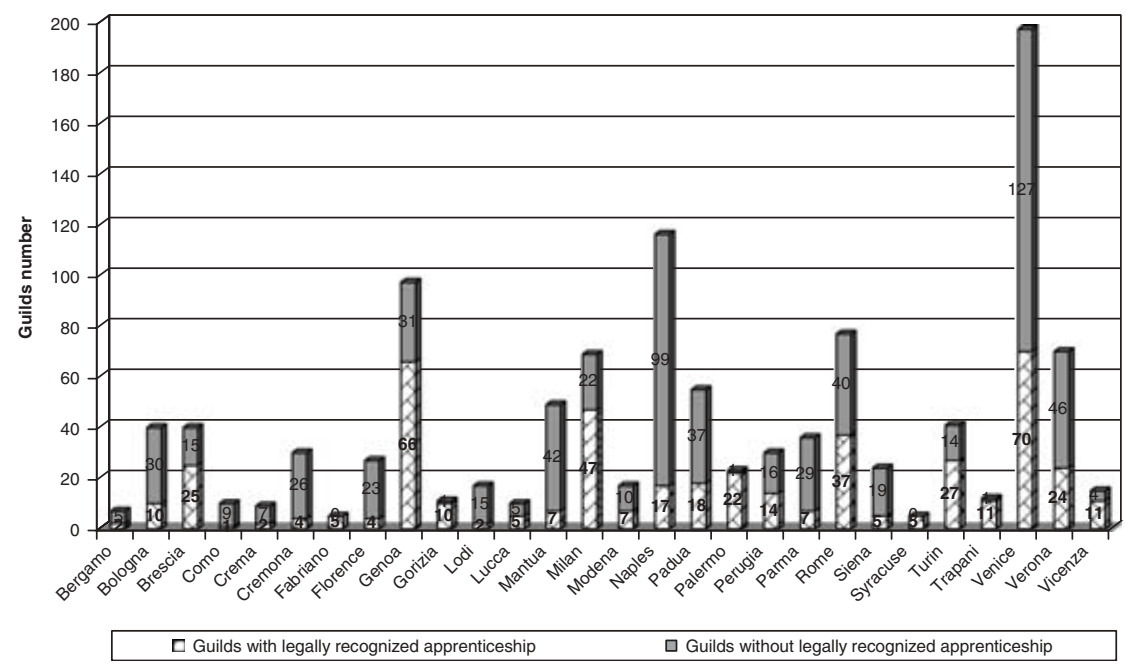

Figure 5. Legally recognized apprenticeship, in various cities in Italy in the early modern period.

The reason for that was the characteristics of the market in the preindustrial era, with no mass demand but a segmented demand where what was most important was the top segment of high-quality goods. That did not create any incentive for innovation on a wide scale, but required instead high-quality standards and stimulated improvement in the actual product. Logically, the guilds pursued policies through technical regulation to favour innovations that would enhance skills and capital-saving innovations. The balance in the control of manufacture would otherwise have tipped in favour of capital holders, because innovations increasing fixed capital costs helped them rather than those who supplied skills.

\section{GUILDS AND APPRENTICESHIP}

With a policy so consciously intended to enhance skills, apprenticeship was the obvious way to achieve the goal of passing on and improving expertise. As many of the processes were labour intensive they positively required the survival of certain skills and the transmission of the appropriate technical knowledge, and that could be guaranteed only by apprentice training. ${ }^{29}$

Figure 5 shows the $\mathrm{I}_{1} \mathrm{I}_{2} 2$ guilds for which it has been possible to reconstruct the presence of apprenticeship schemes. Here too it is possible to see that in the case of most of the guilds recorded (677, or 59.8 per cent), 
apprenticeships were not officially recognized, but that does not necessarily mean the guilds had none. Occasionally, in fact, it has been possible to discover that increasingly commonly, private contracts were adopted which superseded the statutory regulations under which things had been arranged before. A contract was signed between a master craftsman and the parents of a young person who wished to learn his craft. The difference lay in the fact that as there was no longer a statutorily binding minimum length of training, private contracts could result in considerable uncertainty for apprentices. ${ }^{30}$

It is worthwhile noting that in the 445 cases where official recognition of apprenticeship is to be found, most were in the main manufacturing centres of Italy, with Venice, Milan, Turin, and Genoa themselves accounting for almost half of them. It should be emphasized too that the practice of apprenticeship, and for quite long periods, was the norm in high-quality production where superior value would be added, as in silk manufacturing. Rules to regulate the work of apprentices in that sector were to be found in Bologna, Brescia, Genoa, Gorizia, Lucca, Mantua, Milan, Turin, Venice, Verona, and Vicenza - all centres where silk manufacturing was of prime importance. A period of apprenticeship could last anything from four to seven years, with time as an employee to be added to that. In Venice, for example, twelve or thirteen years' training were required to become a fully fledged craftsman.

The length of an apprenticeship was of great importance because, by agreeing to monitor and regulate the market in qualified work, it was possible for guilds to avoid the creation of extreme differences between the demand for and availability of skilled work. Guilds could keep control of the strategic factor in production, which in the pre-industrial era was work, not capital, and prevent its dispersion. There might conceivably have been a definite strategy aimed at fixing a quota on access to positions such as master craftsmen, consigning most workers for ever to the status of mere salaried employees. It is true though that in several cases the distinction between worker and master was purely nominal because in luxury textiles more than any other sector the domestic system prevailed over the craftsman's workshop.

It is possible therefore to claim that most of all in sectors where production was of a high quality, technical regulations and the course of apprenticeship guaranteed by the guilds played an important role in the transmission of skill and knowledge. Some scholars, however, still assert that guilds fought a reactionary battle to defend outmoded skills and

30. This process is clearly demonstrated in Paola Curatolo, "Apprendistato e organizzazione del lavoro nell'industria auroserica milanese (XVI-XVII secolo)", in Elena Brambilla and Giovanni Muto (eds), La Lombardia spagnola. Nuovi indirizzi di ricerca (Milan, 1997), pp. 9I-I09. 
products. It is certainly not possible to make generalizations of that kind however. Let one example suffice: the development of silk-throwing in the guild system in Italy.

During the early modern period silk was a sector in which Italy achieved a leading position through its ability to innovate. Between the Middle Ages and the nineteenth century the guilds with their regulations guaranteed production in Lucca, Bologna, and Turin, three centres which followed each other to the vanguard of throwing technology.

Guilds in Turin were created very late, at the turn of the seventeenth and eighteenth centuries, by express wish of the government, with the twin aims of guaranteeing the standard of thrown silk, which was much in demand on the international market because of its exceptional quality, and the training and protection of the human capital able to produce it. ${ }^{3 \mathrm{I}}$ It is of course true that the policy was based too on the desire to defend a strong position gained in the international market, but it is clear that the position was first attained because of the excellence of the product, guaranteed by the technical procedures adopted.

Alonso has rightly observed, referring to the case of Spain, that "the guilds' resistance to technical change should be studied case by case", and he concluded that,

$[\ldots]$ the reason why many initiatives to introduce technical improvements failed, does in some cases lie with the opposition of the guilds, however in other cases it depends upon the lack of sufficient capital to carry through the innovations, with the weakness of the internal market and, especially, with the lack of a strong commercial network able to channel the sale of the produce. ${ }^{32}$

The question, therefore, is complicated and probably the only way to arrive at convincing answers is to go into some detail, taking the cases of individual towns. This is a methodological choice absolutely indispensable for pre-industrial societies because it was not really states that competed with each other on the international market in manufactured goods, but individual cities. These were cities whose complex economic situations meant their success depended partly on the quality of the relations they kept with their hinterland, and partly on their capacity to secure a significant share of international demand. ${ }^{33}$

31. See Giacomina Caligaris, "Trade Guilds, Manufacturing and Economic Privilege in the Kingdom of Sardinia during the Eighteenth Century", in Guenzi, Massa, and Moioli, Guilds, Markets and Work Regulations in Italy, I6th-19th Centuries, pp. 56-8I.

32. See Alonso, "Guilds, Technical Progress and Economic Development in Preindustrial Spain”, pp. 323 and 326.

33. For the importance of the links between cities and the international market, see the comments of Paul Bairoch, De Jéricho à Mexico: villes et écomies dans l'histoire (Paris, 1985), pp. 232-254; trans. Christopher Braider as Cities and Economic Development: From the Dawn of History to the Present (London, 1988). Competition between urban centres was in fact 


\section{GUILDS COPING WITH SUPPRESSION}

Evidence of the continuing operational capability of the guild system in the pre-industrial economy can be deduced by referring to the problems caused by their suppression, which I will briefly illustrate with reference to the case of Milan. The reason for suppression, finalized in Milan in 1787 , was exclusively political and institutional, for in a new context where distinctions were denied, and the state had established itself as the all-embracing counterpart of society, it was anachronistic to speak of relationships or hierarchies between guilds, or of the privileges of guild members in contrast with non-members. From an economic point of view, the disappearance of the guilds and their substitution by the Chamber of Commerce created numerous problems because of the important role guilds continued to play. I shall mention just a few here.

The fact that there were recognized regulations, such as guild statutes, made it possible to ensure rapid justice in mercantile questions; agreed rules fixed by statutes guaranteed the rights of buyers, while contracts reduced uncertainty; the apprenticeship system played an essential part in technical instruction; the governing bodies of the guilds settled differences between workers and merchants, solving conflicts within their own system. In fact, in the years following their suppression, the Chamber of Commerce was inundated with lawsuits - 5,260 between I788 and I796. ${ }^{34}$

So guilds were still efficient organizations on various fronts in the late eighteenth century: they protected customers, they acted as stabilizers on the urban market; and they cut transaction and organization costs. It is possible to maintain that in Lombardy, although not only there, guilds were eliminated hastily, before the government could implement structural transformations in the manufacturing sector, for example by supporting and promoting centralized manufacturing, and before valid substitutes were set up, such as the factory system.

inevitable since, as Braudel has noted, on the urban markets we see the exchange between city and country, but also between city and city; see Fernand Braudel, L'identità della Francia. Spazio e storia (Milan, I986), p. I68 (a translation by Siân Reynolds from the French appeared as The Identity of France (London, I988)).

34. I have dealt with these aspects in Luca Mocarelli, "Le attività manifatturiere a Milano tra continuità dell'apparato corporativo e il suo superamento (1713-1787)", in Guenzi, Massa, and Moioli, Corporazioni e gruppi professionali nell'Italia Moderna, pp. I3 I-I70, especially pp. $160-170$. 